NBER WORKING PAPER SERIES

INTERGENERATIONAL

TRANSFERS AND SAVINGS

Laurence J. Kotlikoff

Working Paper No. 2237

NATIONAL BUREAU OF ECONOMIC RESEARCH

1050 Massachusetts Avenue

Cambridge, MA 02138

May 1987

I thank Michael Hurd, James Poterba, and Lawrence Summers for helpful comments. The research reported here is part of the NBER's research program in Taxation. Any opinions expressed are those of the author and not those of the National Bureau of Economic Research. 
NBER Working Paper \#2237

May 1987

\title{
Intergenerational Transfers and Savings
}

\begin{abstract}
In recent years the role of intergenerational transfers in the process of wealth accurulation has been the subject of substantial empirical and theoretical analysis. The key question stimulating this research is what is the main explanation for savings? Is it primarily accumulation for retirement as claimed by Albert Ando, Richard Brumberg, and Franco Modigliani in their celebrated Life Cycle Model of Savings? Is it primarily intentional accumulation for intergenerational transfers? Or is it primarily precautionary savings, much of which may be bequeathed because of imperfections in annuity markets?
\end{abstract}

This paper examines a range of findings on the importance of intergenerational transfers. The strong conclusion that emerges from this evidence is that intergenerational transfers play a very important, if not a key, role in aggregate wealth accumulation. While intergenerational transfers figure very large in savings, the precise motivation for such transfers is unclear. Intergenerational altruism might appear the most likely candidate, but at least some stylized facts, such as the equal allocation of bequests among children, are strongly at odds with the altruism model. Other explanations involving imperfect insurance arrangements or payments for child services do not appear capable of explaining the substantial amounts of transfers actually observed. Sorting out the relative contributions of different models to intergenerational transfers and the precise role of intergenerational transfers in the process of wealth accumulation remains an intriguing and exciting enterprise.

Laurence J. Kotlikoff NBER 1050 Massachusetts Avenue Cambridge, MA 02138 
In recent years the role of intergenerational transfers in the process of wealth accumulation has been the subject of substantial empirical and theoretical analysis. The key question stimulating this research is what is the main explanation for savings?. Is it primarily accumulation for retirement as claimed by Albert Ando, Richard Brumberg, and Franco Modigliani in their celebrated Life Cycle Model of Savings? Is it primarily intentional accumulation for intergenerational transfers? $0 r$ is it primarily precautionary savings, much of which may be bequeathed because of imperfections in annuity markets?

The answer to the savings puzzle has many policy implications; certain tax structures are much more conducive to some types of savings than others, and certain government insurance programs might appear less attractive if precautionary motives are the main explanation of savings. Knowledge of the primary savings mechanism would also provide the key to understanding the distribution of wealth.

Solving the savings puzzle requires first collecting the pieces and then seeing how they fit together. A major piece of the puzzle is understanding the quantitative importance of intergenerational transfers to the accumulation of wealth. As I argue below, there is strong evidence that intergenerational transfers play a very important and perhaps dominant role in U.S. wealth accumulation. This does not mean, however, that intentional saving for gifts and bequests is the main saving motive. Significant intergenerational transfers could also arise in the Life Cycle Model in the absence of well functioning private annuity markets or close substitutes for such markets. Let us first look at the evidence on the importance of intergenerational transfers and then turn to the deeper question of why such transfers arise. 


\section{The Importance of Intergenerational Transfers to Savings}

There are six types of evidence concerning the importance of intergenerational transfers to savings. These are: (1) Comparisons of total U.S. wealth with life cycle wealth, defined as the anount of U.S. wealth there would be in the absence of any net intergenerational transfers. The difference between total wealth and life cycle wealth is defined as transfer wealth. These calculations use age-earnings and age-consumption profiles as we 11 as other data, but they do not use data on transfers since they are concerned with what wealth would be in the absence of transfers, (2) the calculation of transfer wealth as defined above using steady state assumptions and the limited reported data on the flow of transfers, (3) zero transfer, life cycle simulation models that attempt to reproduce in a realistic manner actual wealth to income ratios or actual wealth distributions, (4) analysis of the rate of asset decumulation of the elderly, (5) evidence from annuity markets, and (6) historical evidence concerning the correlation of saving rates and changes in the length of retirement. Each of these types of evidence suggests an important role for intergenerational transfers in savings.

A. The Calculation of Life Cycle and Transfer Wealth Components Kotlikoff and Summers (1981) considered the following question: Are the U.S. data broadly consistent with the view that intergenerational transfers play a negligible role in U.S. wealth accumulation? Stated differently, can one reject the null hypothes is that the Life Cycle Model fully explains U.S. wealth. To address this question we divided total wealth, $w$, into two 
components, life cycle wealth, $L$, and transfer wealth, $T$, and defined life cycle wealth of a cohort as the sum over each age of the accunulated difference between past streams of labor earnings and consumption. Total life cycle wealth equals the sum over cohorts of each cohort's life cycle wealth. Let $E$ and $C$ stand, respectively, for the sum over, cohorts of all past accumulated earnings and all past accumulated consumption, then:

$$
W=L+T \text {, and } L=E-C
$$

With this definition of $L$, T equals the sum over cohorts of the sum of accumulated net transfers received at each age. Note that this is the standard definition of life cycle wealth; it is the definition used by Ando and Modigliani (1963), and it is the definition used in the two preceding extensive studies of life cycle wealth accumulation by Tobin (1967) and Darby (1979). It is also the only appropriate definition for testing the zero intergenerational transfer null hypothesis. 1

Calculating $L$ requires knowledge of longitudinal age earnings and age consumption profiles for each cohort. These profiles were derived using data for the period 1900 through 1974 on cross section relative age earnings and age consumption profiles as well as aggregate earnings and consumption. The procedure involved distributing total earnings and consumption in each year by age and sex; combining these cross section age sex matrices of earnings and consumption yields longitudinal profiles that are used to form $E$ and $C$. In our initial paper Sumers and I reported a value of $L$ for 1974 of $\$ 733$ billion, which is only 18.9 percent of total 1974 household mealth of $\$ 3,884$ billion. We subsequently identified an error in the treatment of durables. 
In Kotlikoff and Summers (1986) we indicate that a proper correction for durables raises the share of life cycle wealth to 21.9 percent.

While the 21.9 percent figure is quite small, it is probably an over estinate of the life cycle share of total wealth. In order to generate at least sone positive value for life cycle wealth, Summers and I adjusted upwards standard estimates of the labor income of the self employed by 20 percent. Since the ratio of self employed workers to employees was substantially larger in the prewar period than it is today, the calculated value of life cycle wealth is fairly sensitive to this assumption. Using standard estimates would reduce life cycle wealth by about $\$ 700$ billion. In addition, correcting several other intentional biases in our calculation would produce negative values for life cycle wealth. These include our assumption of a quite high ratio of fenale to male earnings, our assumption of zero earnings after age 75 , and our assumption that the age-consumption profile is flat, rather than declining, after age 75 .

It may be useful to repeat our basic explanation for why life cycle wealth is so small in the U.S. Unlike simple class room depictions of hump saving in which the age consumption is flat and the earnings profile rises to retirement, actual age earnings and age consunption profiles, such as those in Figures 1 and 2 which are reproduced from our paper, have essentially identical shapes and levels prior to at least age 45 . Between ages 45 and 60 there clearly is some hump saving in that earnings profiles exceed consumption profiles; also after age 60 the age consumption profile clearly exceeds the age earnings profile. However, this pattern of hump saving and dissaving (at least relative to earnings) occurs quite late in the life cycle. Hence, one 
would not expect a large accumulation of life cycle wealth in the aggregate since the life cycle wealth of the more numerous generations below age 45 is so small. The simple fact is that consumption does not rise more rapidly through life than labor income.

An earlier study by Darby (1979), that influenced my study with Summers, used cross section data on wealth, earnings, and consumption to divide current wealth holdings into a fraction that would be consumed and a fraction that would be transferred to succeeding generations. Darby concluded that at most 29 percent of U.S. Private net worth is devoted to future consumption, with the rest destined for intergenerational transfer. White (1978) used aggregate data on the age structure of the population, age earnings and age consumption profiles along with a variety of parametric assumption and concludes that the life cycle model can account for only about a quarter of aggregate saving. Though their accounting frameworks are somewhat different and though they use different data, and only cross section data at that, Darby and white reach essentially the same conclusion as Kotlikoff and Summers because the basic shapes of U.S. cross section age earnings and age consumption profiles and the longitudinal profiles that can reasonably be inferred from the cross section profiles are quite different from those of the text book life cycle model.

B. Calculations of Life Cycle and Transfer Wealth Using Flow Data The analyses just described directly calculate life cycle wealth and indirectly infer the stock of transfer wealth. Obviously it would be very useful to corroborate these results with direct evidence on intergenerational transfers. Kotlikoff and Sumers (1981) also examine the available flow data 
on intergenerational transfers. We presented a formula, which is valid only in the steady state, that relates the flow of transfers to the stock of transfer wealth.

There are three major problems with this method for calculating $T$. First, the available flow data on transfers clearly provide a lower bound estimate for total transfer flows; there are no data sources that systematically report intergenerational transfers made in the form of implicit and explicit gifts. Explicit gifts, which may be in kind as well as in cash, are clearly acknowledged as such by donors and recipients. Implicit gifts, such as making one's son an equal partner in a lucrative family business or providing low interest loans to children, may not be viewed as a gift by donors or recipients and would be hard to identify in a survey. Since the U.S. distribution of wealth is highly skewed, implicit gifts, while perhaps small in number, could be very large in value. Hence, any flow estimates of transfer wealth, including those of Modigliani (1984), should be viewed as potentially seriously downward biased.

The second problem with using flow data to calculate $T$ is that the assumption of a steady state may be far from justified. It may be, for example, that the flow of intergenerational transfers in relation to the scale of the economy was much greater in the 1920 s than in the 1960s and 1979s. Not only must one assume that aggregate variables have been in steady state since at least the turn of the century, but one must also assume that the age distribution of transfers is time invariant.

The third problem is that the simple formula given in equation (2) relating transfer wealth $T$ to the transfer flow (the formula incorporates 
Modigliani's (1984) correction for a small error) assumes that everyone dies at the same age D, that all transfers are received at the sane age I, and that all transfers are made at the same age $G$. This is obviously unrealistic, and it is not clear what choice of these three ages best approximates reality. The appropriate choice of these ages depends on one's assunption about the steady state interest and growth rates of the econony, $r$ and $n$, respectively. If half of transfers are received at age 20 and half at age 60 , using 40 for the approximate I would be inappropriate; transfers received at age 20 should receive more weight in the approximation formula because they are accumulated for a much longer period than transfers received at age 60 and because the accumulation formula is a nonlinear function of age.

$$
T=\frac{t}{(r-n)} e^{(r-n) D}\left[1-e^{(n-r)(G-I)}\right] e^{(n-r) I}
$$

To illustrate the implication of the formula, summers and I discussed an example in which D equals 55 (a real world age of death of 73 if the age of adulthood is 18), (G-I) equals 30 , and $(r-n)$ equals .01. Because of our algebraic error we did not assume a value for I. Using a value of I equal to 15 seems justified when $r$ exceeds $n$, because transfer wealth depends on the period of accumulation, and the appropriate approximation to I should be smaller if $r$ exceeds $n$. A similar statement holds for the choice of the age gap (G-I); thus it seems likely that the choice of 30 for (G-I) is too small given that $r$ exceeds $n$. But keeping (G-I) at 30 and choosing I equal to 15 , the factor multiplying the flow of transfers, $t$, in (2) is 39 . Since the estinated 1974 flow of reported transfers is $\$ 45.4$ billion, the "transfer 
flow" lower bound estimate for $T$ is $\$ 1,771$ billion, or 46 percent of 1974 household wealth. Note that using a potentially more appropriate age gap of (G-I) of 45 would yield a lower bound value of $T$ of $\$ 2455$, or 63 percent of total wealth.

One issue about this calculation raised by Modigliani (1984) is whether payment of college tuition by parents should be counted as an intergenerational transfer. Kotlikoff and Summers (1981) defines the age of adulthood as age 18 and treats all payments, either in cash or in kind (including tuition payments), received from parents after age 18 as an intergenerational transfer. Support of children prior to age 18 is considered consumption by the parent. While one may argue about the proper age of adulthood, given the fungibility of money there is no reasonable basis for labelling parental tuition support differently from parental gifts of durables, such as cars, or parental gifts of money; i.e., whether the parent pays tuition or gives the child the money to pay tuition is economically equivalent. In addition, there is no reason to classify somehow educational expenditures as a human as opposed to nonhuman wealth transfer. The transfer of funds to pay for education constitutes a transfer of nonhuman capital. The fact that the expenditure leads to smarter or more skilled children as opposed to, for example, to fatter children, is quite immaterial to the issue of tracing the origins of nonhuman wealth accumulation.

The choice of the age of adulthood is, however, arbitrary. While age 18 seens reasonable for the post war period, it may be too old for older 1974 cohorts, sone of whom were born in the last century. Many of these older generations entered the labor force at younger ages than is currently typical, 
and they certainly had a much shorter lifespan. Indeed, until the 1950s labor force participation rates were calculated for the population over age 14. Had Summers and I used a younger age such as 16 for the age of adulthood for older 1974 cohorts, we would have reported considerably less life cycle wealth.

C. Simulation Studies of Life Cycle Wealth and Comparisons with Actual Wealth Holdings

Simulation analyses also call into question the pure life cycle model. Auerbach and Kotlikoff (1985, 1987) point out, using a detailed life cycle simulation model, that realistic specification of U.S. demographics, preferences, and fiscal institutions implies an extremely small, if not negative, wealth to income ratio. Their results differ from those of Tobin (1967) because of their inclusion of income taxes and social security and their more realistic assumptions concerning the growth rate of consumption over the life cycle. In order to generate substantial life cycle savings Tobin found it necessary to assume that consumption over the life cycle grows at a much faster rate than actually observed. Tobin's calculations which appear to come closest to replicating observed ratios of wealth to income assume that consumption grows at a rate of 5 percent per year over the life cycle. This rate is more than twice the rate actually observed (Kotlikoff and Summers, 1981).

Other simulation studies by Atkinson (1971) and Oulton (1976) point out the difficulty of explaining wealth inequality based on the zero transfer life cycle model. To quote Atkinson, "It is clear from the analys is that life cycle factors cannot explain the upper tail of the current distribution 
of wealth in Britain." Note that the upper tail of the British wealth distribution in Atkinson's study accounts for about three quarters of total British wealth holdings. Both Atkinson and oulton indicate that the substantial inequality in wealth relative to earnings can only be explained by intergenerational transfers.

\section{Asset Decumulation of the Elderly}

Decumulation of wealth after retirement is an essential aspect of the life cycle theory. Yet simple cross section tabulations of wealth holdings by age, Mirer (1979) and Kurz (1984), or saving rates by age, Thurow (1976) and Danziger et al. (1984), do not support the central prediction that the aged dissave. Mirer and Kurz report that wealth holding tends to increase with age.

Thurow reports positive saving rates for persons in all age groups, while Danziger et al. report that saving rates increase with age with "... the elderly spend(ing) less than the nonelderly at the same level of income and (with) the very oldest of the elderly having the lowest average propensity to consume." The most recent cross section study of consumption rates by age is that of Albert Ando (1986); his regression analysis leads him to conclude that "most families follow a reasonably well defined pattern of savings and net wealth accumulation before their retirement, but they tend to dissave little after retirement."

Cross section analysis of estate data by Atkinson (1971) and Atkinson and Harrison (1978) as well as panel analysis of the estates of individual cohorts by Menchik and David (1983) and David and Menchik (1985) also show that the 
average anount of wealth of cohorts rises in old age. Shorrocks' (1975) panel study of the estates of a single cohort in England indicates positive wealth accumulation until age 70. Menchik and David's longitudinal analyses of American estate data is most relevant for understanding U.S. savings behavior. They examine the estates of four birth cohorts living in wisconsin in the period 1947 to 1978 and born between 1880 and 1925 . In addition to studying within cohort behavior, their analyses control for the lifetime earnings of cohort members. Their results "fail to show individuals decumulating wealth in old age."

In contrast to these studies that of King and Dicks-Mireaux (1982), based on cross section Canadian data, suggests a positive rate of decumulation in old age. Burbidge and Robb (1985), on the other hand, reach a somewhat different conclusion from an examination of King and Dicks-Mireaux's data. They report old age asset decumulation only for blue collar workers. For white collar workers the age wealth profile is flat between age 55 and 65 and rises after age 65. Except for the study of King and Dicks-Mireaux, the only other analysis that seems to confirm the Life Cycle Model's prediction of a declining age wealth profile is the panel regression analysis of Diamond and Hausman (1984). However, as both Bernheim (1986) and Hurd (1986) point out, their subsample from the National Longitudinal Survey may not be representative. Indeed, Diamond and Hausman begin their analys is by excluding low wealth households on the grounds that their behavior is inconsistent with the assumptions of the Life Cycle Model. In addition, their data set is not well suited to a study of the wealth of the elderly after they retire because even at the end of the 10 year panel the ages of the sample range from 55 to only 69. 
A number of questions can be raised about many of these analyses of the age wealth profiles and saving rates of the aged. The cross section and several of the cohort analyses (but not those of Menchik and David) may be biased towards a slower rate of asset decumulation because the rich live longer than the poor. In addition, the composition of the sample by age of retirement changes with the age of the sample. Finally, many of these asset decumulation studies fail to take account of the effects of social security and private pensions. As Bernhein (1986) points out, the presence of future social security and pension streams increases the rate of asset decumulation implied by the life cycle model.

Probably the best analyses of asset changes anong the aged are those of Hurd (1986) and Bernheim (1986) both of which use the panel data in the Retirement History Survey. While panel analysis permits holding constant the individual household, one cannot be sure whether changes over time in wealth reflect conscious household saving decisions or are merely the result of unexpected capital gains or losses.

Bernheim considers changes in wealth over two periods, 1969 to 1975 and 1975 to 1979 , for two samples of elderly, the retired and the non retired. He also distinguishes between couples and single individuals. Bernheim's measure of wealth change is the log of the ratio of wealth at the end of the period to wealth at the beginning of the period.

For retired couples Bernhein reports a quite small average rate of asset decumulation (a small average ratio of the logs) for the first period and a small average rate of asset accumulation in the second period. Almost half of retired couples in the earlier period and almost three fifths of couples in 
the latter period exhibited positive rates of asset accumulation. For non retired couples the average rate of wealth change was positive in both periods with roughly three fifths of the non retired elderly engaging in positive accumulation. Non retired single individuals also had positive accumulation on average in both periods, again with about three fifths exhibiting positive saving. The only group whose average rate of wealth change was negative in both periods is retired single individuals. This group displayed a reasonably large rate of asset decumulation on average; but even among this group over two fifths had positive saving.

Bernheim carefully considers these data in light of social security and private pensions and states (1) that "the inclusion of annuities reinforces earlier findings that resources decline only slightly, if at all, after retirement" and (2) that "the pure life cycle hypothesis fails to account for savings behavior after retirement."

Hurd reaches a different conclusion from Bernheim stating "contrary to many results from cross-section data, the elderly do dissave." However, this conclusion appears to be based on tabulations which exclude housing wealth. In addition, one may question Hurd's method of calculating wealth changes; Hurd examines the change in average wealth rather than the average change in wealth. When Hurd includes housing wealth, he reports that average total real wealth of all Retirement History Survey couples declined by only 2 percent between 1969 and 1979. For single individuals Hurd reports a decline of 22.4 percent over the 10 year period in average total wealth. The corresponding figures when housing wealth is excluded are 14.5 percent for couples and 36.4 percent for singles. 
Hurd views the findings on non-housing wealth as most informative arguing that increases in housing wealth in the 1970 s reflect unexpected capital gains. He fails to point out, however, that the reduction in non-housing wealth over the period may reflect unexpected capital losses on stocks and bonds. In addition, the elderly may well have responded to capital gains in housing by accumulating less in other forms; i.e., in the absence of capital gains in housing, non-housing wealth may have been larger.

Hurd's measure may also be more sensitive to measurement error than Bernheim's; the level of average wealth in either 1969 or 1979 may be biased because of outliers. Hurd has indicated (to the author) that the results based on median wealth are similar, but his study, in contrast to that of Bernheim, tells us little about the distribution of wealth changes across the sample.

In sum, the panel studies of Bernheim and Hurd suggest little if any total wealth decumulation of couples and some limited total wealth decumulation of single individuals. In addition, Bernheim shows that a sizeable function of singles as well as couples continues accumulating wealth in old age.

\section{E. Evidence from Annuity Markets}

The strict life cycle model without allowance for bequest motives makes strong predictions about the demand for annuities. Since the date of death is uncertain and since bequests provide no utility, life cycle models imply that there should be a very strong demand for annuity insurance. Indeed, Kotlikoff and Spivak (1981) demonstrate that for the commonly used time separable CES 
utility function of consumption and assuming a risk aversion coefficient of 1.75, the gain to a 55 year old with average mortality probabilities from obtaining access to an actuarially fair annuities market is equivalent to an almost 70 percent increase in his lifetime resources in the absence of such markets.

In fact, the demand for annuities appears to be very weak (J. Friedman and Spivak, 1986). Friedman and Warshawsky (1984) report that the loads on annuity insurance are no higher than the loads on other frequent ly purchased types of insurance such as property and casualty insurance. Yet annuity purchases are a rarity. Friedman and Wahrshawsky argue that it is necessary to assume a fairly strong bequest motive to explain this behavior. Friedman and Wahrshawsky do not, however, take into account uncertainty with respect to inflation risk, which may explain the reluctance of many to purchase nominal annuities. In addition, totally annuitizing one's wealth might leave one illiquid and unable to pay major one time expenses such as medical care. Still, the virtual nonexistence of annuity insurance is quite surprising. Kotlikoff and Spivak (1981) advance a possible alternative explanation, namely that families will self insure to a large extent when annuity insurance is only available on very unfavorable terns; family insurance, however, does not appear capable of fully accounting for the widespread failure to annuitize. Bernheim, Shleifer, and Sumers (1985) review a number of settings where annuities are available on a fair or even subsidized basis and report that even in these cases there is little demand for annuities. They conclude from this evidence that many consumers must have significant bequest motives. Their strongest evidence comes from TIAA-CREF's 1973 Survey of Beneficiaries. 
In this survey over 70 percent of beneficiaries chose plans other than those providing full annuity protection despite the fact that TIAA-CREF annuities appear to be quite close to actuarially fair.

F. Historical Evidence

The essential prediction of the life cycle theory is that people save to prepare for their retirement when they must dissave and consume. Without periods of retirement, or at least, significant decreased labor earnings at the end of life there is no life cycle motive for saving. Yet there were substantial positive net national saving rates (net national saving divided by net national product) over the period 1870 to 1930 when retirement was much less common than it is today.

As Ransom and Sutch (1986) show, there was some retirement in the latter part of the last century and the pre-Depression years of this century, but the retirement rate of the elderly was small, especially when compared with current rates. During the period 1870 to 1930 the labor force participation rate of males 60 and older was essentially constant at 64 to 65 percent. In contrast, the current rate for males 60 and older is 30 percent; for males 65 and older the 1900 Ransom-Sutch estimate is 58 percent compared with a current rate of 17.5 percent. Life expectancy for age 20 males during the period 1870 to 1930 appears to have been about 65 ; for much of the post war period it has been above 70 .

Despite this significant increase in the length of retirement, the saving rate in recent decades has been substantially smaller than that observed between 1870 and 1930 . The average saving rate, defined as net national 
saving divided by net national product, recorded from 1870 to 1930 is close to 50 percent greater than the average saving rate in the post war period. 2 In contrast to the Life Cycle Model, at least one class of bequests models suggests that saving rates may rise with the length of retirenent (Skinner, 1985).

of course, much besides the length of retirement changed over the last century, so the negative correlation between the saving rate and the length of retirement may be spurious. It is, therefore, also useful to examine this correlation over shorter periods. Kotlikoff and Smith (1983) report that since 1950 the expected duration of retirement and other nonworking periods for the average adult has almost doubled. This change coincided with a secular decline of almost 40 percent in the net national saving rate. of course, the introduction of unfunded Social Security (Feldstein, 1974) and other government policies way have reduced saving since 1950, but the life cycle model would still predict a quite substantial offsetting impact arising from the change in retirement (Kotlikoff, 1979).

\section{Understanding Intergenerational Transfers}

A. Explanations for Intergenerational Transfers Altruistic concern for one's children is the first reason one thinks of for intergenerational transfers. This concern way be expressed mathematically as the parent having direct utility for the utility of the child as in Barro (1974) and Becker (1974). An alternative, nonaltruistic codel of bequests (Yarri (1966) and Blinder (1973)) is that parents care about the level of the bequest per se. But a utility of the size of the bequest nodel seens 
implausible because it implies that the parent's transfer to the child is independent of the child's economic circumstances.

The altruistic model also seems somewhat implausible because it has such strong neutrality predictions. As is well known, Barro (1984) showed that intergenerational transfers by the government are completely neutralized because parents internalize the effects on all future generations of such transfers. More recently Kotlikoff (1983) and Bernheim and Bagwell (1985) independently showed that marriage may altruistically link large numbers of parents and other extended family members (if not the entire planet), with the implication that intragenerational government transfers will also be entirely neutralized. The utility of the child's consumption model also appears to have strong neutrality properties.

The neutrality properties of the altruistic models hold only if transferors are not constrained in their transfers. As an example of such constraints, suppose an altruistic parent would like to transfer from her children to herself, and the parent can not compel her children to make such transfers; in this situation, government redistribution from that parent to her child will have real effects.

An alternative view of transfers from parents to children, which has nothing to do with parental concern for children or a desire per se to leave bequests, is that parents and children form an incomplete annuities market (Kotlikoff and Spivak, 1981). According to this view parents and children enter into implicit risk sharing arrangements. The risk to be shared is the parent's longevity risk. The arrangement involves parents agreeing to transfer their assets to their children at death as a quid pro quo for support 
payments from the children if the parents live longer than expected. Enforcement of such arrangements is enhanced by having the child make payments to the parent each year, rather than wait until the parent runs out of resources.

Kotlikoff, Shoven, and Spivak (1985) denonstrate that significant intergenerational transfers could arise in the aggregate in a dynamic equilibrium model of imperfect family annuity insurance. Indeed, they point out that such a model could explain much of the 80-20 split of transfer and life cycle wealth reported by Kotlikoff and Summers (1981). This point is important; it indicates that although intergenerational transfers way be large in the aggregate, fundamental preferences may still correspond to those posited in the generationally selfish life cycle model.

Other researchers, including Sheshinski and Weiss (1981), Davies (1981), Eckstein, Eichenbaum, and Peled (1983), Abel (1983), and Hubbard (1984a, 1984b), have examined the potential for intergenerational transfers when no annuity insurance whatsoever, including implicit family insurance, is available. These studies also demonstrate clearly that significant intergenerational transfers can arise in the life cycle model if annuity insurance is unavailable. 3

Even if the life span were certain, individuals may save significant sums for the possibility of substantial end of life medical and nursing home expenses. If such wedical problems do not arise, the elderly individual may be unable to consume this nest egg before he or she dies, and, consequently, a bequest will arise.

Other individuals may simply strike it rich in their professions and investments and find themselves unable to consume all their resources. It's 
clear that consumption satiation does occur; there are enough exanples of extremely wealthy individuals, many who are quite young, who are unable to consume their wealth over their lifetime, especially when one properly neasures consumption as excluding expenditures on durables, but including imputed rent on durables. Additional research is needed to determine how substantial windfalls influence total wealth accunulation. While there is some contradictory evidence concerning the bequest-resource elasticity (Menchik and David, 1983; Kotlikoff, 1977), this elasticity surely exceeds unity for the super wealthy.

Bernheim, Shleifer, and Summers (1985) advance a forth explanation for intergenerational transfers, namely as the implicit payment by parents to their children for providing in kind services, such as assisting them with chores, trips to the doctor, etc. While some intergenerational transfers surely arise as payments for child provided services, it seems quite unlikely that such transfers would be very large in the aggregate.

Each of these explanations of intergenerational transfers presumablyplays some role in explaining aggregate transfers; in addition, there are probably many traditional life cycle households that are well annuitized through private pensions and Social Security and, consequently leave no intergenerational transfers. This heterogenous view of preferences and insurance arrangements is espoused by Kurz (1984).

B. Empirical Tests of Alternative Models of Intergenerational Transfers Empirical analysis of intergenerational transfers has been greatly liaited by the available data. To test models of altruism or fanily insurance 
arrangements one needs data not only on the transfers, consumption choices, and resources of parents, but also those of adult children; i.e., One needs information on the extended family. At the present time there simply are no suitable data sets covering the extended family.

There are, however, data on intervivos transfers and bequests. In his analysis of 379 Connecticut estates with bequests to children with siblings Menchik (1980) finds strong evidence that "wealth bequeathed to children is shared equally." This study confirmed earlier findings by Sussman, et al. (1970) and Brittain (1978). On the other hand, Tomes' (1981) findings based on recall data from cleveland contradict the equal bequest view; but in 1985 Menchik (1985) sampled actual probate records in cleveland and found equal division in 93 percent of the cases. The finding of equal bequests strongly contradicts the prediction of the altruistic model which predicts that differences in bequests would compensate for differences in children's earnings capacities. Donald Cox (1987) reports another finding at odds with altruism, namely that transfers are positively related to the recipient's income level.

Hurd (1986) also finds evidence against the utility of bequest model, and indirectly against the altruism model. Hurd points out that parents with bequest motives should consume their end of 1 ife resources at a slower rate than those with bequest motives. He then compares the rate of asset decumulation of the elderly who have children with those who do not. He finds no significant difference in the rate of asset decumulation among the two groups.

Bernheim, Schleifer, and Sumers (1985) report that in settings with two or more children, children of richer parents spend more time with their 
parents than children of poorer parents. In contrast, they find no significant impact of parental wealth on the visitation of only children. The authors view these findings as strong support for their aodel in which parents with two or more children credibly threaten to disinherit those children who are insufficiently attentive. These findings, while suggestive, must be viewed as preliminary; further analysis, taking account of childrens' own wealth position, is needed.

In addition to these micro analyses of intergenerational transfers, Boskin and Kotlikoff (1985) use time series data to test directly one of the key neutrality propositions of the altruism model, namely that aggregated consumption is independent of the age distribution of resources. Their model assumes extended families have identical Barro type preferences and identical demographic structures. Under these assumptions aggregate household consumption depends simply on the present value of aggregate human wealth, plus national net worth, less the present value of future government consumption. It is independent of the age distribution of resources. Boskin and Kotlikoff show that given the appropriate resource variables, the age composition of income still significantly influences aggregate consumption. Thus they reject their admittedly stylized model of intergenerational altruism.

III. Conclusion

Like most good puzzles, the saving puzzle has a lot of pieces, many of which don't seem to fit together. It seems well established that intergenerational transfers are sizeable and that the process leading to 
these transfers is responsible for a sizeable anount of wealth accumulation. The precise explanation for these transfers remains unclear.

Intergenerational altruism might appear the most likely candidate, but at least some stylized facts, such as the equal allocation of bequests anong children, are strongly at odds with the altruism model. Other explanations involving imperfect insurance arrangements or payments for child services do not appear capable of explaining the substantial amounts of transfers actually observed. Sorting out the relative contributions of different models to intergenerational transfers and the precise role of intergenerational transfers in the process of wealth accumulation remains an intriguing and exciting enterprise. 


\section{Footnotes}

1. Modigliani (1984) prefers a different definition of life cycle wealth, $L_{m}$, where $L_{m}$ equals the sus over cohorts of the sum of saving at each age, and saving is defined as income less consumption. The problem with his definition is that income may include capital income earned on previously received intergenerational transfers. Hence, since income itself may reflect intergenerational transfers, the sum of saving out of income can not be used to test with maximum power the null hypothesis that the zero transfer life cycle model accounts for essentially all of U.S. mealth. Stated differently, under the null hypothesis, $L_{m}=L$, but if there are significant intergenerational transfers $L_{m}$ could be close to $W$, although both $L_{m}$ and $W$ would be substantially different from L. Indeed, Ando (1986) reports calculations of $L_{\text {n }}$ equal to 65 percent to 75 percent of $W$ for the period 1960 to 1970 , while our 1974 calculation of $L$ is only 21.9 percent of $1974 \mathrm{~W}$.

2. Historical Statistics, p. 231, and The 1987 Economic Report of the President.

3. I find these life cycle models somewhat unsatisfactory because they simply assume away annuity insurance despite the fact that life cycle agents will have very substantial demands for annuities. In addition, the bequests arising in these models are arbitrarily allocated to children despite the fact that the parents have no bequest motive. 


\section{References}

Adams, Bert. Kinship in an Urban Setting. Chicago: Markham Publishing Company, 1968.

Ando, Albert. "Selected Comments on Current Empirical Evidence for or Against the Life Cycle Theory." Paper presented at The International Seminar on the Life Cycle Theory, Paris, 1986.

Ando, Albert and Franco Modigliani. "The Life Cycle Hypothesis of Saving: Aggregate Implications and Tests," American Economic Review, March 1963.

Atkinson, A. B. "The Distribution of Wealth and the Individual Life Cycle," Oxford Economic Papers, 1971.

Atkinson, A. B. and A. J. Harrison. The Distribution of Wealth in Britain. Cambridge: Cambridge University Press, 1978.

Auerbach, Alan J. and Laurence J. Kotlikoff. Dynamic Fiscal Policy. Cambridge: Cambridge University Press, 1987.

Auerbach, Alan J. and Laurence J. Kotlikoff. "Simulating Alternative Social Security Responses to the Denographic Transition," Mational Tax Journal. June 1985.

Becker, Gary S. "A Theory of Social Interactions," Journal of Political Economy, November/December 1974, 1063-94.

Becker, Gary S. and Nigel Tomes. "An Equilibrium Theory of the Distribution of Incone," Journal of Political Economy, December 1979, 1153-89.

Becker, Gary S. and Migel Tomes. "Child Endowments and the Quantity and Quality of Children," Journal of Political Economy, 1976, 84, S143-S162. Behraan, J., R. Pollak, and P. Taubman. "Parental Preferences and Provision 
for Progeny," Journal of Political Economy, 1982.

Bernheim, B. Douglas. "Dissaving After Retirement: Testing the Pure Life Cycle Hypothesis," in Issues in Pension Economics. NBER volume.

Chicago: University of Chicago Press, 1986.

Bernheim, B. Douglas and Kyle Bagwell. "Is Everything Neutral?" Mimeo, 1985.

Bernheim, B. Douglas, Andrei Shleifer, and Lawrence H. Summers. "Bequests as

a Means of Payment," Journal of Political Economy, 1986.

Blinder, Alan. "A Model of Inherited Wealth," The Quarterly Journal of

Economics, 1973 .

Boskin, Michael J. and Laurence J. Kotlikoff. "Public Debt and U.S. Saving: A New Test of the Neutrality Hypothesis." Carnegie-Rochester Conference Volume Series, February, 1986.

Brittain, John A. Inheritance and the Inequality of Material Wealth.

Washington, D.C.: The Brookings Institution, 1978.

Burbridge, J. B. and A. L. Robb. "Evidence on Wealth Age Profiles in Canadian Cross Section Data," Canadian Journal of Economics, November 1985.

Cox, Donald. "Motives for Private Income Transfers," Journal of Political Economy, 1987.

Danziger, S., J. Van der Gaag, E. Smolensky, and M. Taussig. "The Life Cycle Hypothesis and the Consumption Behavior of the Elderly," Journal of Post Keynesian Economics, 1983.

Darby, Michael R. Effects of Social Security on Income and the Capital Stock. Washington, D.C.: American Enterprise Institute, 1979.

David, Martin and Paul L. Menchik. "The Effect of Social Security on Lifetime 
Wealth Accumulation and Bequests," Economica, 1985.

Davies, James. "Uncertain Lifetine, Consumption, and Dissaving in

Retirement," Journal of Political Economy, June 1981.

Diamond, Peter A, and Jerry Mausman. "Individual Retirement and Savings Behavior," Journal of Public Economics, 1984.

Eckstein, Zvi, Marty Eichenbaum, and Dan Peled, "Uncertain Lifetimes and the Welfare Enhancing Properties of Annuity Markets and Social Security." Mineo, 1983.

Feldstein, Martin S., "Social Security, Induced Retirenent, and Saving." The Journal of Political Economy, 1974.

Feldstein, Martin S. "Mational Saving in the United States," in Jobs, Shapiro and White, eds, Capital for Productivity and Jobs, by The Anerican Assembly, Columbia University. Englewood Cliffs, NJ:

Prentice Hal1, 1977.

Friedman, Benjamin and Mark Warshanky. "The Cost of Annuities: Implications

for Saving Behavior and Bequests." MBER Working Paper No. 1682.

Cambridge, Mass.: Mational Bureau of Economic Research, August 1985. Friedman, Joseph and Avia Spivak. "The Demand for Annuities." Mimeo, 1986. Hubbard, Glenn R. "Uncertain Lifetiwes, Pensions, and Individual Saving." MBER Working Paper No. 1363. Cambridge, Mass.: National Bureau of Economic Research, $1984 a$.

Hubbard, Glenn R. "Precautionary Saving Revisited: Social Security, Individual Welfare, and the Capital Stock," $1984 \mathrm{~b}$. Hurd, Michae1. "Savings and Bequests." MBER Working Paper No. 1826. Cambridge, Mass.: National Bureau of Economic Research, January 1986. Ishikawa, Tsuneo. "Fanily Structures and Faaily Values in the Theory of 
Incore Distribution," Journal of Political Economy, October 1975, 987-1008.

Kotlikoff, Laurence J. "Estimating the Elasticity of Bequests with Respect to Lifetime Resources from A Sample of Potential Decedents," Mimeo, 1977. Kotlikoff, Laurence J. "Some Economic Implications of Life Span Extension," in Biology and Behavior of the Aged, National Institute of Aging, Academic Press, 1982.

Kotlikoff, Laurence J. "Theoretical and Empirical Analysis of Altruistic Linkages Within the Extended Family." Mimeo, June 1983. Kotlikoff, Laurence J. "The Impact of Annuity Insurance on Savings and Inequality," Journal of Labor Economics, 1986.

Kotlikoff, Laurence J., John Shoven, and Avia Spivak. "Annuity Market's Savings, and the Capital Stock." NBER Working Paper No. 1250. Cambridge, Mass.: National Bureau of Economic Research, 1984. Kotlikoff, Laurence J. and Daniel E. Smith. Pensions in the American Economy. Chicago: University of Chicago Press, 1983. Kotlikoff, Laurence J. and Avia Spivak. "The Family as an Incomplete Annuities Market," Journal of Political Economy, April 1981, 372-91. Kotlikoff, Laurence J. and Lawrence H. Summers. "The Role of

Intergenerational Transfers in Aggregate Capital Accumulation," Journal of Political Economy, 1981, 89 (3).

Kurz, Mordecai. "Capital Accunulation and the Characteristics of Private Intergenerational Transfers," Economica, February $1984 a$.

Kurz, Mordecai. "The Life Cycle Hypothesis as a Tool of Theory and Practice." Mineo, $1984 b$.

Lawrence, Emily. "Do Transfers to the Poor Reduce Savings?" Mimeo, 1983. Loury, Glen. "Intergenerational Transfers and the Distribution of Earnings," 
Econometrica, 1981.

Menchik, Paul L. "Primogeniture, Equal Sharing, and the U.S. Distribution of Wealth," The Quarterly Journal of Economics, 1980.

Menchik, Paul L. "Unequal Estate Division: Is it Altruism, Reverse Bequests, or Simply Noise?" Paper presented to the 1984 Seminar on Modelling the Accumulation and Distribution of Wealth, Paris, France, 1985.

Menchik, Paul and M. David. "Income Distribution, Life Time Saving and Bequests," The American Economic Review, September 1983.

Mirer, Thad W. "The Wealth Age Relation Among the Aged," American Economic Review, June 1979.

Modigliani, Franco. "The Contribution of Intergenerational Transfer to Total Wealth." Paper presented to the Paris Conference on Modeling the Accumulation and Distribution of Wealth, September 1984.

Modigliani, Franco. "The Life Cycle Hypothesis of Saving, Twenty Years Later," in M. Parkin, ed., Contemporary Issues in Economics. Manchester University Press, 1975, 2-36.

Modigliani, Franco and Richard Brumberg. "Utility Analysis and Aggregate Consumption Functions: An Attempt at Integration," in A. Abel, ed., The Collected Papers of Franco Modigliani. Cambridge, Mass.: The MIT Press, 1980.

Modigliani, Franco and Richard Brumberg. "Utility Analys is and the Consumption Function: An Interpretation of Cross Section Data," in K. K. Kurihara, ed., Post Keynesian Economics. New Brunswick, NJ: Rutgers University Press, 1954, 388-436.

(The) President's Council of Economic Advisors. "The 1987 Economic Report of 
the President." Washington, D.C.: U.S. Government Printing Office, 1987.

Ransom, Roger L. and Richard Sutch. "The Labor of Older Americans:

Retirement of Men On and Off the Job, 1870 to 1937," The Journal of Economic History, March 1986.

Seidman, Laurence S. "Taxes in a Life Cycle Growth Model with Bequests and Inheritances," American Economic Review, June 1983.

Sheshinski, Eytan and Yoram Weiss. "Uncertainty and Optimal Social Security Systems," Quarterly Journal of Economics, May 1981.

Shorrocks, Anthony F. "The Age Wealth Relationship: A Cross Section and Cohort Analysis," Review of Economics and Statistics, 1975.

Skinner, Jonathan. "The Effect of Increased Longevity on Capital Accumulation," American Economic Review, December 1985.

Solow, Robert. "Reflections on Saving Behavior," in Saving and Government Policy. Conference Series No. 25. Boston: Federal Reserve Bank of Boston, 1982.

Summers, Lawrence H. "Capital Taxation and Capital Accumulation in a Life Cycle Growth Mode1," American Economic Review, September 1981.

Sussman, M. B., J. N. Cates, and 0. T. Smith. Inheritance and the Family. New York: Sage, 1970.

Thurow, Lester. Generating Inequality. Basic Books, 1976.

Tobin, James. "Life Cycle Saving and Balanced Growth," in Willian Fellner, et al., eds., Ten Economic Studies in the Tradition of Irving Fisher. New York: Wiley, 1967, 231-56.

Tones, Nigel. "The Family, Inheritance, and the Intergenerational 
$-31-$

Transmission of Inequality," Journal of Political Economy, October 1981, 928-58.

U.S. Department of Census. Historical Statistics of the United States.

Washington, D.C.: U.S. Government Printing office, 1975.

White, Betsy Buttrill. "Empirical Tests of the Life Cycle Hypothesis,"

American Economic Review, September 1978, 68 (4), 547-60.

Mari, Menachim E. "Uncertain Lifetime, Life Insurance, and the Theory of the Consumer," Review of Economic Studies, 1965. 


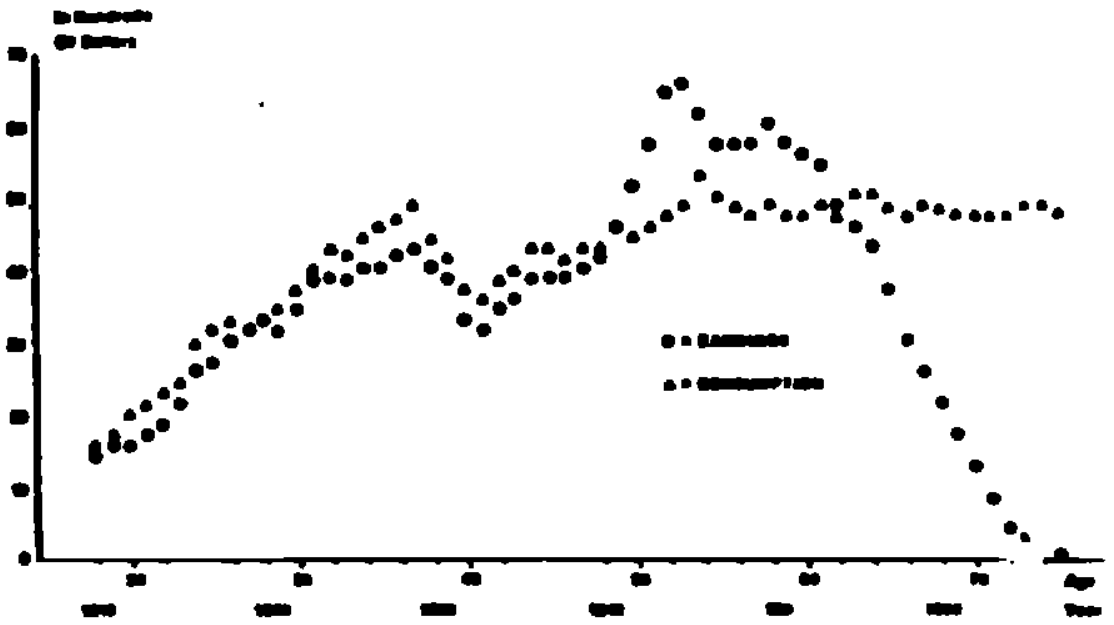

Tuc: 1. - Sum of male and female longihudinl average en rning aud average conump-

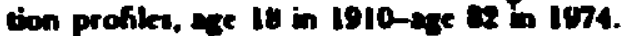

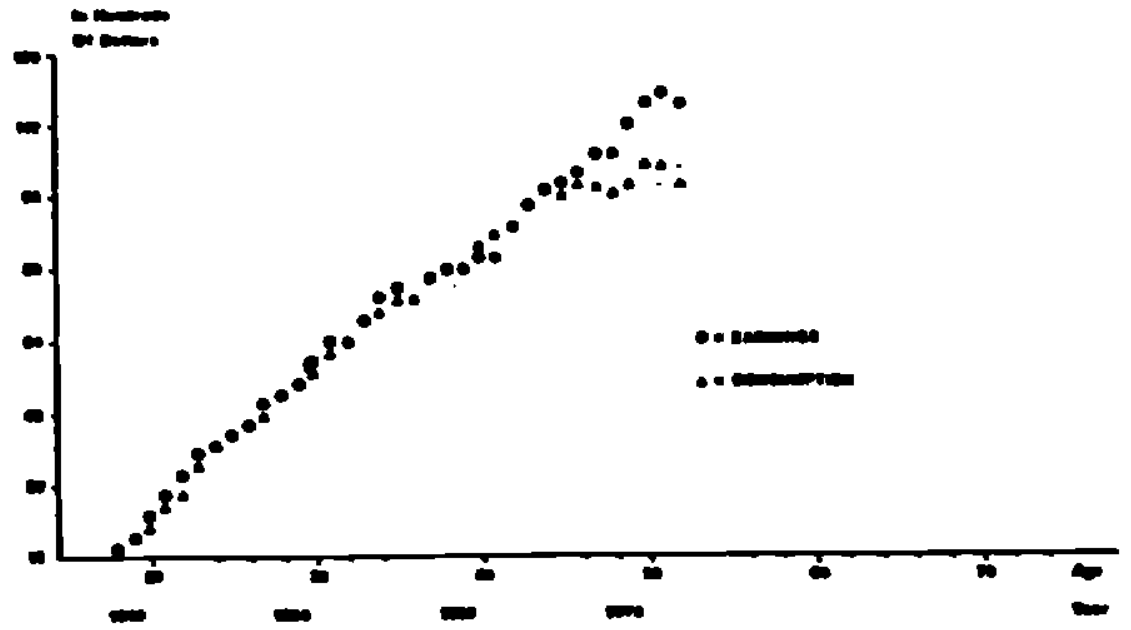

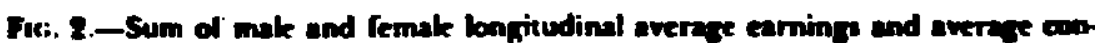

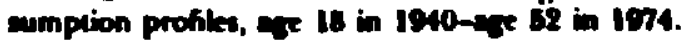

